\title{
O testemunho na lgreja: elemento-chave de credibilidade dentro da tarefa apologética-dialogal da Teologia Fundamental de Pié-Ninot
}

Orientadora: Maria Teresa de Freitas Cardoso

Mestrando: Luiz Cláudio Moraes Correia

Área de Concentração: Teologia Sistemático-Pastoral

Linha de Pesquisa: Religião e Modernidade

O tema do testemunho cristão é o foco principal deste trabalho. Segundo Salvador Pié-Ninot, na sua Teologia Fundamental, o testemunho se apresenta como a nova via empírica, isto é, o novo caminho que, através da vida cotidiana da Igreja com suas experiências diversas, por vezes até paradoxais, se apresenta como motivo coerente e plausível para se crer. Afinal, o testemunho é como que uma condição primeira necessária à credibilidade da fé. Isso é importante na tarefa apologético-dialogal da Teologia Fundamental. Dentro desta, na parte da Eclesiologia Fundamental, o testemunho é tido como elemento-chave de credibilidade na Igreja e passa a ser conhecido como "via testimonii", por ser o caminho mais enfático, notório e coerente para a evangelização. A perspectiva do testemunho que, segundo Pié-Ninot é "sempre teológico", dá-se no testemunho eclesial como "mistério envolto em paradoxo". O testemunho cristão conduz à tarefa apologética, facilitando o diálogo na Igreja, quer pessoal (pela oração a Deus e Liturgia), quer com os irmãos (diálogo ecumênico e inter-religioso); e na diaconia do serviço de amor ao próximo.

Palavras-chave: Testemunho. Credibilidade. Igreja. 